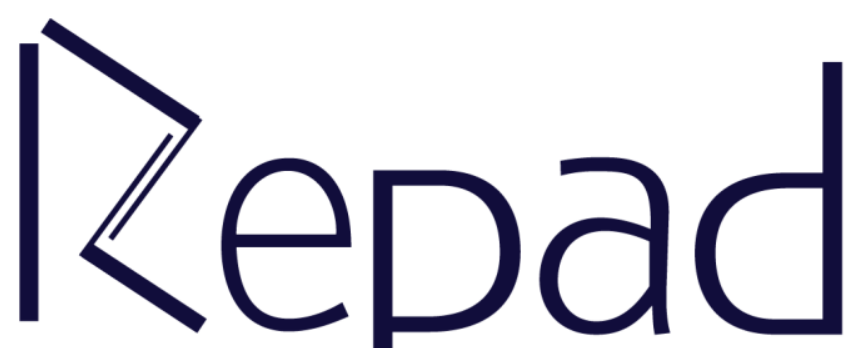

vol. 3, n. 3, Setembro-Dezembro/2019

Revista Estudos e

Pesquisas em Administração 


\title{
UMA ANÁLISE DOS CONGLOMERADOS FINANCEIROS NO RECENTE CICLO ECONÔMICO BRASILEIRO
}

\author{
Rômulo Bernardo dos Santos \\ Universidade Federal Fluminense, Rio de Janeiro, Rio de Janeiro, Brasil \\ romulobernardo@hotmail.com \\ https://orcid.org/0000-0003-4336-0375 \\ Rodrigo Milano de Lucena \\ Universidade Federal Fluminense, Rio de Janeiro, Rio de Janeiro, Brasil \\ milano.rodrigo@hotmail.com \\ https://orcid.org/0000-0001-5560-0802
}

\begin{abstract}
Resumo
O presente trabalho buscou analisar, sob a perspectiva da Hipótese de Fragilidade Financeira de Hyman Minsky, como os cinco maiores conglomerados financeiros que atuam no Brasil se comportaram na gestão de suas estruturas patrimoniais entre 2007 a 2016. Para tanto, foram utilizados dados da plataforma digital IFdata disponibilizada pelo Banco Central do Brasil que concede a possibilidade de analisar a evolução da estrutura patrimonial dos conglomerados financeiros que atuam na economia brasileira. Como método de análise foram calculados índices que mensuram o grau de alavancagem e a composição dos ativos das instituições financeiras. Verificou-se que em períodos de expansão da atividade econômica, como o período observado na economia brasileira entre 2007 a 2013, os cinco maiores conglomerados financeiros se expuseram a maiores riscos (devido a melhoria nas expectativas dos empresários e a necessidade de ampliar o Market share) ampliando consequentemente em sua estrutura patrimonial ativos com menor liquidez e consequentemente maior rendimento. Já em períodos de desaceleração da atividade econômica e grande incerteza com relação ao comportamento dos indicadores macroeconômicos, como se verificou na economia brasileira no período que compreende aos anos 2014 a 2016, as instituições financeiras expandiram operações que possuíam maior margem de segurança, ampliando na composição de suas estruturas patrimoniais ativos que possuíam maior liquidez. Os resultados supracitados estão de acordo com a base teórica explicitada.
\end{abstract}

Palavras-chave: Fragilidade Financeira; Conglomerados Financeiros; Economia Brasileira

\section{AN ANALYSIS OF FINANCIAL CONGLOMERATES IN THE RECENT BRAZILIAN ECONOMIC CYCLE}

\begin{abstract}
The present paper sought to analyze, based on the Hyman Minsky hypothesis of financial Fragility, how the five largest financial conglomerates of Brazil behaved in the management of their equity structure between 2007 and 2016. For that, data from the Central Bank of Brazil were used. As a method of analysis, we use indicators that measure the degree of leverage and composition of the assets of financial institutions. It was verified that in periods of economic activity expansion, such as the period observed in the Brazilian economy between 2006 and 2013, the five largest financial conglomerates were exposed to higher risks (due to the improvement in entrepreneurs' expectations and the need to increase the participation of the market), consequently increasing their asset
\end{abstract}


structure with lower liquidity and, consequently, higher income. In times of economic slowdown and great uncertainty about the behavior of macroeconomic indicators, as occurred in the Brazilian economy, in the period from 2014 to 2016, financial institutions expanded operations that had greater margin of safety, increasing the composition of their asset structures greater liquidity. The results founds agreed with the theoretical base used. Keywords: Financial Fragility; Financial Conglomerates; Brazilian Economy.

Submetido: $26 / 09 / 2019$

Aceito: 07/11/2019

Publicado: 31/12/2019

\section{INTRODUÇÃO}

Diferentes autores, sob diferentes perspectivas teóricas, buscaram entender qual seria o papel do sistema bancário na determinação da atividade econômica. Segundo a abordagem convencional neoclássica, os bancos estão condicionados a um papel passivo no que se refere às alterações nas condições e estruturas de financiamento da economia. Consequentemente, as instituições financeiras não afetariam de forma direta a dinâmica a atividade econômica. $\mathrm{Na}$ abordagem teórica supracitada, os bancos detêm como principais funções apenas mobilizar, intermediar e alocar recursos entre agentes superavitários e deficitários (PAULA, 2015).

Esta visão passiva acerca do papel dos bancos, pode ser verificada em Klein (1975), que desenvolve um modelo matemático que tenta descrever o comportamento dos bancos, em que se pesa seu comportamento maximizador de lucro, em uma estrutura de mercado estritamente competitiva. $\mathrm{O}$ autor tenta demonstrar como os bancos alcançam o equilíbrio em sua escala, tomando decisões para alcançar o ponto ótimo na composição de seus ativos e passivos - tendo, por sua vez, os depósitos como dado - "Such supply functions denote, for each price, the expected value of the deposit liabilities the bank will assume" (KLEIN, 1975, p. 210).

A abordagem pós-keynesiana diverge contundentemente da visão neoclássica no que tange ao papel dos bancos em uma economia monetária da produção ${ }^{1}$. Nesta perspectiva os bancos possuem um papel central e ativo nas economias modernas, graças à sua capacidade de alterar as condições e estruturas de financiamento. Soma-se a estes fatores, o entendimento de que os bancos guiam ativamente suas operações financeiras, levando em consideração suas expectativas com relação a atividade econômica. Portanto, os bancos atuam na gestão de suas estruturas patrimoniais através de alterações na composição de seus ativos e criação de estratégias para adequar seus passivos à conjuntura econômica vigente, tendo como objetivo primordial manter a maximização do lucro.

Levando em consideração o papel dos bancos na teoria pós-keynesiana, acreditase que os grandes conglomerados financeiros que atuam no Brasil alteraram bruscamente suas estruturas de balanço patrimonial nos anos recentes, uma vez que, a economia

\footnotetext{
${ }^{1}$ Uma economia monetária da produção apresenta os seguintes fundamentos: i) As firmas são maximizadoras de lucro; ii) A decisão de investir provém das firmas; iii) A produção ocorre de forma cronológica; iv) Não há pré-conciliação de planos entre os agentes; v) Não há ergodicidade; e vi) A moeda não é neutra. Keynes (1996), Carvalho (1988), Oreiro (2011).
} 
brasileira sofreu com dramáticas alterações nas políticas econômicas e consequentemente no comportamento de suas variáveis macroeconômicas.

A economia brasileira cresceu em média aproximadamente $4,5 \%$ a.a. entre 2004 e 2010 em que se pesa melhorias na qualidade de vida das pessoas, com aumento nos índices de distribuição de renda, manutenção da estabilidade no nível de preços e redução do endividamento público. Torna-se importante ressaltar, o surpreendente resultado supracitado, mesmo com a grave crise que afetou a economia mundial em 2008. Já no decorrer do Governo Dilma Rousseff (2011-2014), a economia brasileira apresentou considerável arrefecimento da atividade econômica apresentando uma média de crescimento do PIB de 2,4\% a.a. entre os anos 2011 a 2014.

O biênio 2015-2016, por sua vez, foi caracterizado por sucessivas quedas nos indicadores macroeconômicos, revelando um período de grave crise econômica, em que se observaram aumentos sucessivos das taxas de desemprego, quedas drásticas no Produto Interno Bruto real, desaceleração de importantes setores da economia brasileira e reversão das expectativas dos empresários. Nestes diferentes cenários, torna-se preponderante analisar como os cinco maiores conglomerados financeiros (a saber: Banco do Brasil, Itaú, Bradesco, Caixa Econômica Federal e Santander) se comportaram na gestão de suas estruturas patrimoniais entre os anos 2007 (um ano antes da eclosão da crise mundial) a 2016.

Defende-se, portanto, que no período caracterizado pela expansão da atividade econômica os conglomerados financeiros, graças ao otimismo que vigorava na economia e a necessidade de ampliar o marketshare, tenham ampliado o grau de alavancagem de suas operações financeiras, expandindo em estruturas patrimoniais a presença de ativos com elevados níveis de rentabilidade e consequentemente menor grau de liquidez. Já no período de retração dos indicadores macroeconômicos e consequente piora das expectativas dos empresários com relação ao comportamento da economia, argumenta-se que houve alterações significativas na composição patrimonial dos grandes bancos, caracterizadas por quedas contínuas em seus níveis de alavancagem e expansão da participação de ativos com menor rentabilidade e maior grau de liquidez em suas estruturas patrimoniais. A fim de verificar as hipóteses, foram coletados dados disponibilizados na plataforma digital IF.data do Banco Central do Brasil no decorrer de 2017 e construídos índices que buscaram auferir o grau de alavancagem das instituições financeira e a evolução de suas estruturas patrimoniais no ciclo econômico recente (20072016).

Os indicadores Ativo Total/Patrimônio Líquido e Operações de crédito/ Patrimônio Líquido demonstram o grau de alavancagem e de exposição a possíveis insolvências das instituições financeiras nas diferentes fases do ciclo econômico que caracterizaram o período analisado. Já os índices Operações de Crédito/ Ativo Total e Aplicações em Títulos Financeiros/ Ativo Total demonstram a composição e a gestão da estrutura patrimonial dos bancos analisados. A construção dos indicadores supracitados concederá a possibilidade de analisar se nos períodos de expansão da atividade econômica (2007-2013) os bancos buscaram reduzir a margem de segurança e ampliar a rentabilidade de suas operações. Este processo seria verificado pela ampliação do grau de alavancagem das instituições financeiras e pelo crescimento da participação das operações de crédito na estrutura patrimonial nestes conglomerados.

Já no período caracterizado pela retração dos indicadores macroeconômicos da economia brasileira (2014-2017) os índices calculados demonstrarão se houve queda no grau de alavancagem e ampliação da proporção de aplicações financeiras em títulos em 
detrimento da queda participação das operações de crédito em suas estruturas patrimoniais. Estas operações demonstrariam que os bancos analisados buscaram ampliar a margem de segurança de suas operações financeiras devido a grave incerteza que assolou a economia brasileira. Após a elaboração dos indicadores supracitados buscouse confrontar os resultados encontrados com a literatura econômica pós-keynesiana.

A discussão, além desta Introdução, se deu em três seções e uma conclusão. $\mathrm{Na}$ segunda seção foi descrito a Hipótese da Fragilidade Financeira (HFF) e as estratégias que os bancos possuem, segundo Hyman Minsky, na gestão de suas estruturas patrimoniais em diferentes conjunturas econômicas. Já na terceira seção demonstraremos a evolução dos indicadores macroeconômicos da economia brasileira entre os anos 2007 a 2016. Na quarta seção, por sua vez, foram apresentados os dados que tratam da evolução da estrutura patrimonial dos cinco maiores conglomerados financeiros nos anos analisados.

\section{HIPÓTESE DA FRAGILIDADE FINANCEIRA}

Após a grave crise que afetou os Estados Unidos e consequentemente a economia mundial em 2008, um grande debate acerca da literatura que trata da análise macroeconômica se iniciou; questionando diversos pontos acerca do então vigente Novo Consenso Macroeconômico que vigorava desde os inícios dos anos 2000. As obras de Hyman Minsky ganharam crescente notoriedade no debate macroeconômico graças à consistente demonstração da importância central que os bancos possuem no funcionamento das economias modernas, e como estes influenciam de maneira preponderante os ciclos econômicos constantemente presentes nas economias capitalistas. Minsky (1992) aponta que os ciclos de negócio (business cycle) são resultado da própria dinâmica das economias capitalistas, o que as torna endogenamente instáveis. Consequentemente, contrariamente ao defendido pela teoria neoclássica, não são choques exógenos que desviam a economia de sua suposta tendência ao equilíbrio macroeconômico, mas sim seu próprio funcionamento.

Paula (2015), levando em consideração a Hipótese da Fragilidade Financeira, aponta que os bancos e as firmas propiciam o caráter instável das economias capitalistas. $\mathrm{O}$ argumento que as economias modernas apresentam comportamento cíclico está pautado na maneira de como as instituições supracitadas financiam suas atividades. $\mathrm{O}$ autor demonstra que em momentos de expressivo crescimento econômico, há retração da percepção dos riscos que envolvem as transações financeiras por parte dos agentes econômicos, deixando a economia mais exposta à eventuais choques e ampliando consequentemente sua fragilidade financeira.

Minsky (1992) demonstra como os ciclos econômicos ocorrem nas economias capitalista e como os bancos e empresas propiciam este comportamento cíclico. Segundo o autor, a economia transitaria em três posições financeiras, a saber: Hedge, Speculative e Ponzi. A posição Hedge aponta para uma economia que possui unidades financeiras "conservadoras", ou seja, nestas unidades o fluxo de caixa é suficiente para saldar todos as obrigações, inclusive os compromissos financeiros. Logo, há grande participação de capital próprio na estrutura de financiamento, consequentemente menor vulnerabilidade dessas unidades à choques externos que poderiam afetar sua estrutura de financiamento, como por exemplo alterações na taxa de juros do mercado. Já a posição financeira Speculative aponta para uma economia que possui unidades financeiras mais expostas ao risco, por estas terem margem de segurança inferior no que se refere aos recursos disponíveis para saldar suas obrigações. Unidades financeiras especulativas, não possuem 
recursos próprios (por meio do fluxo de caixa) para saldar o montante principal de suas dívidas, sendo necessário rolar suas dívidas no mercado, através por exemplo, de emissão de novas dívidas, a fim de honrar com estes recursos, as obrigações financeiras já existentes. A necessidade destas unidades financeiras rolarem suas dívidas, gera uma maior exposição da economia à choques exógenos e consequentemente a eventuais crises financeiras. Uma elevação na taxa de juros, por exemplo, gerará uma expansão dos custos financeiros destas unidades, tornando inviável economicamente a rolagem destas dívidas para saldar as obrigações já existentes. Quando estas unidades, não conseguem arcar com seus contratos financeiros, há uma crise financeira. (MINSKY 1986, 1992). Já a posição financeira Ponzi, segundo Paula (2015), se refere a uma situação extrema em que as unidades financeiras não possuem receitas suficientes para cobrir os juros de suas obrigações financeiras. Neste caso, estas unidades buscam recursos no mercado para cobrir os juros devidos, ampliando continuamente o montante principal e os encargos de suas obrigações financeiras. Quando as unidades financeiras se encontram na postura financeira supracitada, há uma crescente fragilização financeira da economia, pois alterações nas condições macroeconômicas terão grande impacto nos custos destas unidades, ampliando a possibilidade de crises financeira devido à impossibilidade destas unidades honrarem suas obrigações.

Fonseca (2018) aponta que os ciclos econômicos (business cycle) que caracterizam as economias capitalistas têm seu início após o término de uma crise econômica. Neste momento as unidades financeiras - firmas e bancos - buscam novos negócios e maneiras de financiá-los. Como os indicadores macroeconômicos ainda estão em franca recuperação, estas unidades iniciam suas operações em um tipo de posição financeira Hedge, ou seja, com elevada parcela de capital próprio suficientes para cumprir suas obrigações. Com a expansão da atividade econômica e consequente melhoria das expectativas dos empresários, as firmas expandem suas operações, ampliando a demanda por crédito elevando consequentemente os custos de obtê-los. As firmas então assumem posições de financiamento mais arriscadas, como a Speculative descrita anteriormente.

Estas unidades impulsionadas pelo crescimento dos indicadores macroeconômicos e pela melhoria das expectativas, ampliam a rolagem de suas dívidas, já que não possuem recursos suficientes oriundo do fluxo de caixa para saldá-las. Este processo avança até o momento que as receitas já não são suficientes para arcar nem mesmo com os juros do montante principal dos compromissos financeiros. Neste momento, a firma transita para uma posição financeira Ponzi, em que as firmas recorrem à novos empréstimos para saldar obrigações financeiras já existentes. Neste momento, qualquer alteração nas condições de financiamento como, por exemplo, uma retração de crédito por parte dos bancos devido à adoção de uma política monetária restritiva gera graves crises econômicas, levando a economia ao estado inicial do ciclo econômico. (FONSECA, 2018)

Como os bancos, em uma perspectiva teórica Pós-Keynesiana, detêm a capacidade de criar moeda através do multiplicador bancário, estas instituições detêm a capacidade de gerar empréstimo sem a necessidade de depósitos prévios. Portanto cabe à estas instituições financeiras o controle sobre a oferta de crédito aos agentes econômicos no decorrer do ciclo econômico e consequentemente a determinação do volume de crédito que estará disponível no mercado nas economias capitalistas. Se torna então importante, analisar como os bancos se comportam na gestão de sua estrutura patrimonial no decorrer das diferentes fases que compõem o ciclo econômico descrito por Minsky, levando em consideração as situações conflitantes que os bancos enfrentam. (PAULA, 2015). Na 
perspectiva teórica Pós-Keynesiana os bancos enfrentam uma situação conflitante entre optar por ativos que possuam maior liquidez ou rentabilidade. As instituições financeiras baseiam suas operações levando em consideração uma característica central de uma economia monetária da produção: a incerteza (PAULA; ALVES JÚNIOR, 2003).

Keynes (1996) demonstra em a "Teoria Geral do Emprego, do Juro e da Moeda" que há um trade-off entre liquidez e retornos monetários. A Teoria da Precificação dos Ativos, descrita na equação 1 , aponta que a taxa de juros do próprio ativo (r) deve ser igual a seu rendimento $(\mathrm{q})$, deduzindo o custo de carregamento do ativo (c) e levando em consideração o prêmio pela liquidez deste (l).

$$
r=a+q-c+l \quad(\text { equação } 1)
$$

Os bancos assim como os demais agente econômicos, portanto, enfrentam uma situação de conflito na gestão de seus recursos em optar por operações que envolvam ativos que tragam maiores rendimentos $(\mathrm{a}+\mathrm{q}-\mathrm{c})$ ou que tragam maior segurança representada pelo grau máximo de liquidez da moeda (1). (PAULA,2015). Como os bancos são instituições dinâmicas que atuam na gestão de suas estruturas patrimoniais alterando a composição tanto de seus ativos quanto de seu passivo, estes adotam estratégias distintas nas diferentes fases dos ciclos econômicos. $\mathrm{Na}$ fase expansionista, levando em consideração os indicadores macroeconômicos e as expectativas otimistas acerca do comportamento da economia, ampliam suas operações (ativo) de crédito e adiantamentos respondendo a demanda do mercado. A ampliação de operações de crédito com maiores prazos, aponta para operações que resultem em maior rentabilidade e menor liquidez, levando estas instituições financeiras à um grau maior de alavancagem em suas operações e retrações de suas margens de segurança (PAULA; ALVES JÚNIOR, 2003).

No que se refere à administração do passivo na fase ascendente, os bancos buscam maneiras de ampliar seus recursos - através de estratégias que conduzam seus clientes a por aplicações de longo prazo como o depósito a prazo, criação de inovações financeiras - com o objetivo de alavancar suas operações. Já no que se refere a estratégias de operações (ativo) na fase descendente do ciclo econômico, em que as expectativas sobre o comportamento da economia se deterioram, os bancos optam por ativos de maior liquidez, reduzindo consequentemente operações de crédito de longo e médio prazo (que por sua vez agravam a crise econômica, uma vez que, impede a rolagem das dívidas de instituições que apresentam posições financeiras especulativas ) e ampliando operações de elevada liquidez, como por exemplo, títulos do governo. Assim os bancos tentam ampliar suas margens de segurança e manter a maximização dos lucros dado o cenário econômico vigente. (PAULA, 2015). No que se refere a administração do passivo na fase descendente do ciclo econômico, os bancos tentam reduzir seu grau de alavancagem alterando a composição do passivo através da ampliação de capital próprio em sua composição e retração de recursos de terceiros. O Quadro 1 sintetiza as estratégias de gestão patrimonial dos bancos, nas duas fases do ciclo econômicos descritas no decorrer deste trabalho.

Conforme descrito no decorrer desta seção, os bancos na gestão de sua estrutura patrimonial levam em consideração as expectativas com relação aos indicadores macroeconômicos, a fim de optar pela melhor estratégia para manter a maximização do lucro. Como citado na introdução deste trabalho, o período que compreende aos anos 2007 a 2016, apresentou importantes inflexões na política econômica e consequentemente nos indicadores econômicos da economia brasileira, alterando provavelmente $\mathrm{o}$ 
comportamento dos cinco maiores conglomerados financeiros que atuam no Brasil no que tange à administração tanto de seus ativos quanto do passivo.

Quadro 1 - Gestão Patrimonial dos Bancos na fase ascendente e descendente do ciclo econômico

$\begin{array}{lllll}\begin{array}{l}\text { Ativos na fase } \\ \text { ascendente }\end{array} & \begin{array}{l}\text { Disponibilidades } \\ (-)\end{array} & \begin{array}{l}\text { Títulos Públicos e } \\ \text { Privados (-) }\end{array} & \begin{array}{l}\text { Empréstimos de } \\ \text { curto prazo }(-)\end{array} & \begin{array}{l}\text { Empréstimos de } \\ \text { longo prazo }(+)\end{array} \\ \begin{array}{l}\text { Passivo na fase } \\ \text { ascendente }\end{array} & \begin{array}{l}\text { Depósito à vista } \\ (+)\end{array} & \text { Depósito a prazo (+) } & \begin{array}{l}\text { Empréstimo } \\ \text { (Redesconto e }\end{array} & \begin{array}{l}\text { Patrimônio Líquido } \\ (-)\end{array} \\ & & & \begin{array}{l}\text { Interbancário) } \\ (+)\end{array}\end{array}$

$\begin{array}{lllll}\begin{array}{l}\text { Ativos na fase } \\ \text { descendente }\end{array} & \begin{array}{l}\text { Disponibilidades } \\ (+)\end{array} & \begin{array}{l}\text { Títulos Públicos e } \\ \text { Privados }(+)\end{array} & \begin{array}{l}\text { Empréstimos de } \\ \text { curto prazo }(+)\end{array} & \begin{array}{l}\text { Empréstimos de } \\ \text { longo prazo }(-)\end{array} \\ \begin{array}{l}\text { Passivos na fase } \\ \text { descendente }\end{array} & \text { Depósito à vista } & \text { Depósito a prazo (-) } & \begin{array}{l}\text { Empréstimo } \\ \text { (Redesconto e }\end{array} & \begin{array}{l}\text { Patrimônio Líquido } \\ (-)\end{array} \\ & (-) & & \begin{array}{l}\text { Interbancário) } \\ (-)\end{array} & \end{array}$

Fonte: Paula e Alves Júnior (2003).

Nota: Os sinais (+) e (-) significam aumento ou redução da importância da rubrica.

\section{BREVE ANÁLISE DA ECONOMIA BRASILEIRA (2006-2016) \\ 3.1 Economia Brasileira (2007-2013)}

As políticas econômicas adotadas no segundo governo de Luiz Inácio Lula da Silva (2006-2010) divergem substancialmente das medidas econômicas que tinham sido implementadas até o primeiro mandato do governo Lula (2003-2006). Após a adoção de políticas tanto fiscais quanto monetárias de cunho "ortodoxo" que tinham como objetivo conquistar a confiança do mercado no primeiro mandato presidido pelo Partido dos Trabalhadores, há uma inflexão nas políticas econômicas, adotando-se a partir de então políticas fiscais expansionistas com o objetivo de gerar expressivo crescimento na economia brasileira.

A partir de 2006 o governo ampliou o alcance e os recursos destinados aos programas de transferências de renda como o Bolsa Família e priorizou políticas de reajustes do salário mínimo que concederam maior poder de compra para as famílias brasileiras. Essas políticas econômicas, conjuntamente com a ampliação ao acesso a crédito a pessoas físicas estimularam a expansão do consumo agregado (BARBOSA; SOUZA, 2010).

Em 2007, o governo lançou o Programa de Aceleração do Crescimento (PAC) que tinha como objetivo expandir os investimentos em infraestrutura e solucionar antigos gargalos em áreas estratégicas como: energia, transporte, habitação, recursos hídricos, entre outros. O PAC detinha um orçamento inicial de R $\$ 504$ bilhões e foi considerado um programa de extrema importância para o crescimento da economia brasileira pois elevou os investimentos da União, de 0,3\% do PIB em 2005 para 0,8\% do PIB em 2010, e das empresas estatais no período entre 2005 a 2010 - 1\% do PIB em 2005 para 1,9\% do PIB em 2010- , gerando grande crescimento da formação bruta de capital fixo, exceto no biênio 2008-2009 devido aos efeitos da crise mundial que abalou negativamente o resultado do Produto Interno Bruto (Gráfico 1) (CARDOSO JÚNIOR; NAVARRO, 2016). 
Bielschovsky; Squeff; Vasconcelos (2015) destacam ainda a ampliação das exportações que caracterizou a economia brasileira entre os anos 2006 a 2010, o crescimento desta variável se deve em grande medida ao deslocamento do centro econômico mundial à China, importante demandante de commodities produzidas no Brasil. A economia brasileira então apresentou considerável expansão da atividade econômica, demonstrada no crescimento do Produto Interno Bruto (Gráfico 1), em que se pesa expansão do consumo das famílias, ampliação dos investimentos em infraestrutura e expansão das exportações.

Gráfico 1 - Produto Interno Bruto (Variação Anual em \%)

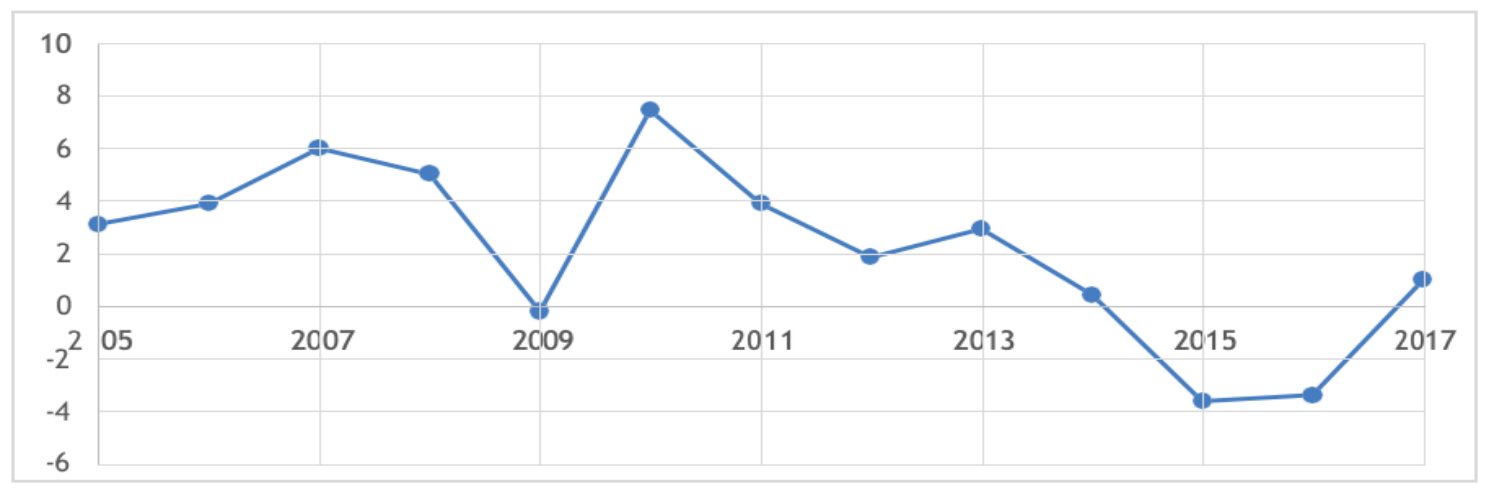

Fonte: Elaborado pelos autores a partir de dados do IBGE (2017)

Segundo Mello e Rossi (2017), houve arrefecimento da atividade econômica no quadriênio 2011-2014 graças à adoção de diferentes políticas econômicas que não geraram os resultados esperados. O expressivo crescimento do produto em 2010, e, por conseguinte, no nível de renda, gerou apreensão no governo recém-eleito de um crescimento efetivo do produto acima do nível potencial e de seus consequentes malefícios como o avanço de eventuais pressões inflacionárias.

Para Serrano e Suma (2015), numa tentativa de cumprir a meta de superávit primário, o governo promoveu a redução dos investimentos públicos na ordem de 17,9\%, que somados a redução de 7,8\% nos investimentos das empresas estatais, foram os principais responsáveis da queda da atividade econômica de 7,5\% no ano de 2010 para 4\% em 2011, conforme o Gráfico 1.

Segundo Singer (2015) o governo insatisfeito com a queda drástica nos indicadores macroeconômicos no primeiro ano do governo Dilma Rousseff, alterou drasticamente a política econômica até então implementada. Buscou-se adotar inúmeras políticas econômicas - que ficaram conhecidas como Nova Matriz Econômica (NME) - com o objetivo de estimular a oferta agregada da economia brasileira através de incentivos à produção.

O autor aponta que: i) a redução da taxa básica de juros (SELIC) em 2012 para o menor valor de sua história $(7,5 \%)$ buscava incentivar a queda da taxa de juros praticadas pelo mercado a fim de reduzir os custos financeiros para o setor produtivo, ii) o governo a fim de incentivar o setor industrial concedeu desonerações fiscais à 42 setores da economia, com o objetivo de incentivar o investimento privado, iii) o governo ampliou a oferta de crédito via Banco Nacional de Desenvolvimento Econômico ampliando o financiamento à investimentos de médio-longo prazo iv) redução das tarifas de energias elétrica com o objetivo de reduzir os custos operacionais das grandes indústrias, entre 
outros, foram medidas que visavam fortalecer a indústria nacional e incentivar a ampliação do investimento privado na economia brasileira (SINGER, 2015).

O fato é que a NME não atingiu seu objetivo primordial que era de modernizar a estrutura produtiva e ampliar os investimentos privados. Mello e Rossi (2017) apontam que ainda que de forma tímida, a estratégia econômica do governo apresentava resultados positivos com a ampliação da formação bruta de capital fixo, à pequenas taxas, até a metade de 2013, ano em que ocorreu uma forte reversão da taxa. Entretanto este resultado estava aquém do esperado pelo governo que esperava um forte crescimento dos investimentos e crescimento econômico, que não se concretizou, pois houve significativa queda do PIB em média no período de 2011 a 2014 (2,4\%) comparado aos anos do governo Lula.

\subsection{Economia Brasileira (2014-2016)}

A economia brasileira entrou tecnicamente em recessão em 2014, depois de apresentar dois trimestres seguidos de retração do Produto Interno Bruto. O biênio 20152016, por sua vez apresentou queda em praticamente em todos os indicadores macroeconômicos. O Produto Interno Bruto apresentou queda de 3,5\% em 2015 e 3,3\% em 2016 (gráfico 3). A Tabela 1, demonstra retração nos resultados dos principais componentes da demanda agregada -Formação Bruta de Capital Fixo, Consumo do governo, Consumo das Famílias (CORRÊA; LEMOS; FEIJO, 2017).

Tabela 1 - Taxas de crescimento médias ao ano do PIB, e componentes da agregada períodos selecionados $(\mathrm{em} \%)$

\begin{tabular}{ccccccc}
\hline Período & PIB & $\begin{array}{c}\text { Consumo } \\
\text { Famílias }\end{array}$ & $\begin{array}{c}\text { Consumo } \\
\text { Governo }\end{array}$ & FBCF* & Exportação & Importação \\
\hline $1996-2003$ & 2,0 & 1,4 & 1,5 & 0,2 & 7,6 & 0,7 \\
$2004-2010$ & 4,5 & 5,3 & 3,2 & 8,2 & 5,4 & 14,0 \\
$2011-2014$ & 2,4 & 3,5 & 1,7 & 2,3 & 1,6 & 3,9 \\
$2015-2016$ & $-3,7$ & $-4,1$ & $-0,8$ & $-12,0$ & 4,1 & $-12,2$ \\
\hline
\end{tabular}

Fonte: Retirado de Corrêa et al. (2017)

Nota. *Formação Bruta de Capital Fixo

Lacerda (2017) aponta que a retração da atividade econômica entre os anos 2014 a 2016 decorre da política econômica implementada no período- ajuste fiscal-, observouse corte nos investimentos públicos (em todas as esferas da administração pública) sob o pretexto de ampliar o superávit primário com o objetivo de estabilizar a dívida pública e crescimento expressivo da taxa de juros para manter a inflação na meta estabelecida pelo Banco Central. Os fatores supracitados contraíram expressivamente a demanda agregada e estimularam ainda mais o processo de financeirização da economia brasileira que já estava em curso, uma vez que a ampliação da Selic estimula aplicações financeiras em detrimento do investimento em capital produtivo.

Corrêa, Lemos e Feijó (2017) apontam que o crescimento da economia brasileira entre os anos 2006 a 2010 e consequentemente a melhoria nas expectativas dos empresários geraram ampliação da demanda de crédito com o objetivo de obter recursos para ampliar suas atividades (com considerável crescimento do endividamento em moeda estrangeira) por parte de Empresas não financeiras. Este processo, por sua vez, levou a economia brasileira a uma posição de fragilidade financeira especulativa ou Ponzi, uma vez que, estas empresas não detinham capital próprio para saldar suas obrigações financeiras e recorriam ao mercado de crédito para rolar suas dívidas. A reversão do 
cenário externo - crise de 2008 e reversão da política econômica da China que alterou o foco de sua política econômica para a demanda doméstica - gerou reversão do cenário macroeconômico e reversão das expectativas, caracterizando segundo Corrêa, Lemos e Feijó (2017), a fase descendente do ciclo econômico descrito por Minsky no biênio 20152016.

\section{Gestão Patrimonial dos Cinco Maiores Conglomerados Financeiros}

A economia brasileira, portanto, apresentou uma fase de intensivo crescimento que compreende aos anos 2006 a 2013, excetuando-se o biênio 2008-2009 devido as consequências da crise mundial. Torna-se importante ressaltar que entre os anos 2011 a 2013 há o arrefecimento da atividade econômica brasileira, porém a economia brasileira ainda apresentava indicadores positivos com relação ao crescimento econômico. No triênio 2014-2016, por sua vez, a economia brasileira apresenta quedas drásticas nos indicadores da atividade econômica, caracterizando a fase descendente do ciclo econômico.

Torna-se essencial, portanto, analisar como se comportaram os indicadores de crédito e participação dos bancos na estrutura de financiamento da economia brasileira no ciclo econômico supracitado. Os Gráficos 2 e 3 apontam para um crescimento da oferta de crédito tanto de bancos que estão sobre o controle privado (Gráfico 2) quanto dos bancos que estão sob controle público (Gráfico 3) entre os anos 2007 a 2013.

Gráfico 2 - Saldo das operações das instituições financeiras sob controle privado - Total R\$ (milhões)

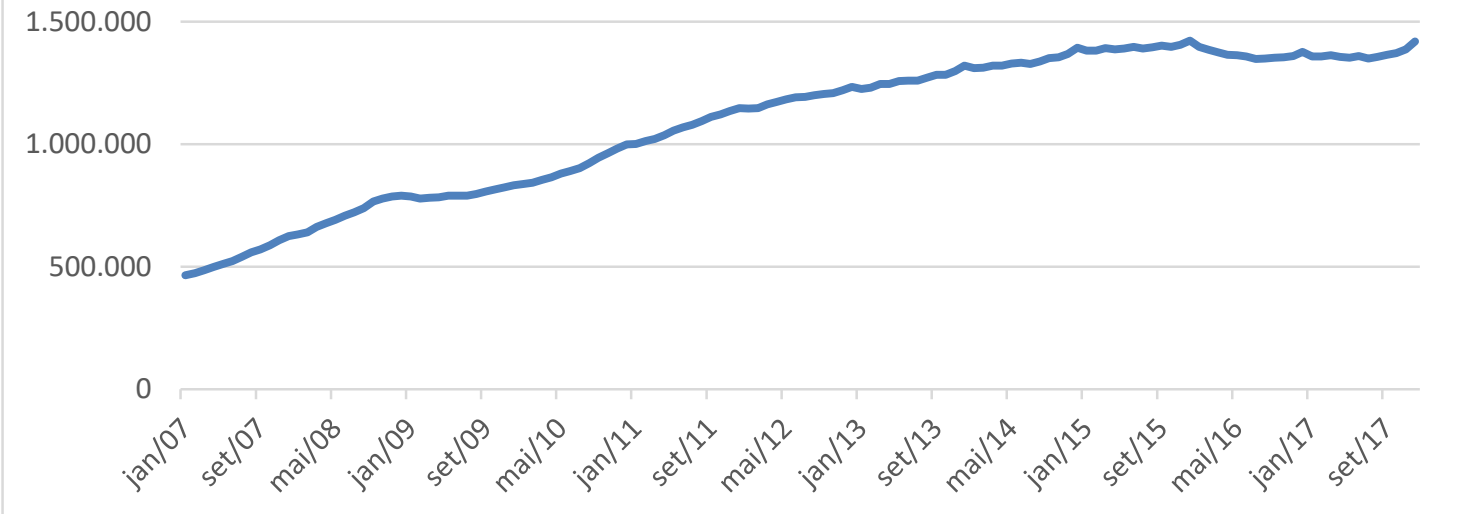

Fonte: Elaborado pelos autores com dados do Banco Central (2017)

Gráfico 3 - Saldo das operações de crédito das instituições financeiras sob controle público Total R\$ (milhões)

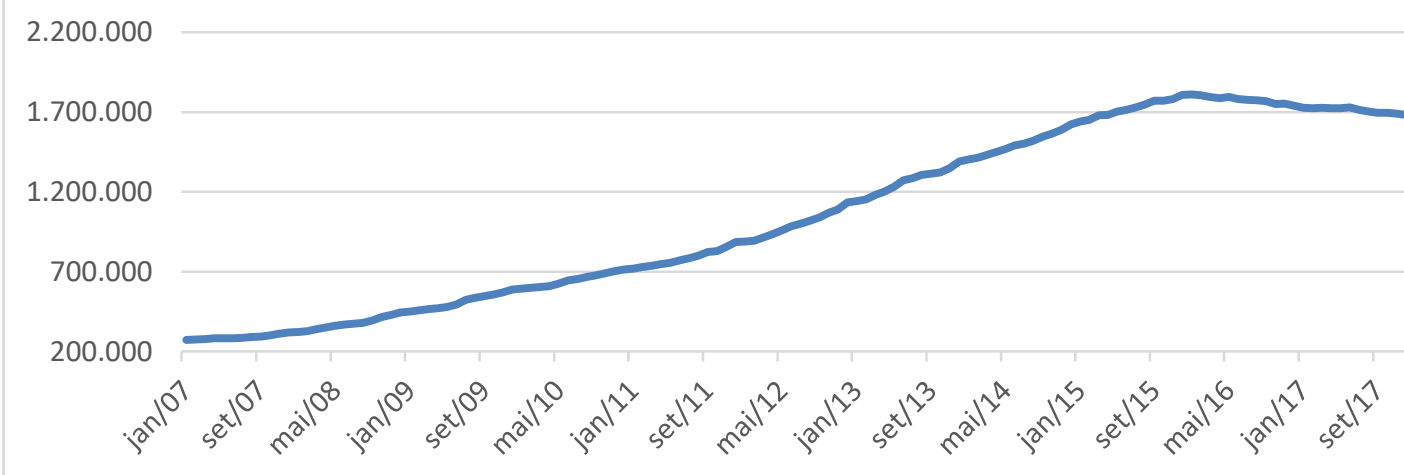

Fonte: Elaborado pelos autores com dados do Banco Central (2017) 
Já no decorrer da fase descendente, verifica-se a queda na oferta de crédito das instituições sob controle privado, principalmente em 2015 (Gráfico 2) e retração da oferta de crédito em instituições que estão sob controle público (Gráfico 3). Estes resultados estão em consonância com a Hipótese da Fragilidade Financeira descrita na primeira seção deste trabalho.

Mendonça e Cavalcante (2018) analisaram as posturas financeiras que os grandes bancos assumiram entre os anos 2004 a 2016 através da criação de um Índice de Fragilidade Financeira (IFFB1). Este índice leva em consideração: i) a proporção dos ativos da instituição financeira em relação ao seu patrimônio líquido ii) o quantitativo de obrigações financeiras ilíquidas e, por fim, iii) a inadimplência em relação as operações de crédito, excluindo destas; operações que representam baixo risco. O Gráfico 4 aponta que dentre os cinco maiores bancos que atuam no Brasil, três apresentaram permanentemente uma posição especulativa (IFBB1 > 1) - Banco do Brasil, Caixa Econômica Federal e Santander. Já o Itaú e o Bradesco apresentaram posturas financeiras mais conservadoras entre 2004 a 2016, oscilando entre a posição Hedge e Speculative.

Gráfico 4 - IFFB1 dos Grandes Bancos

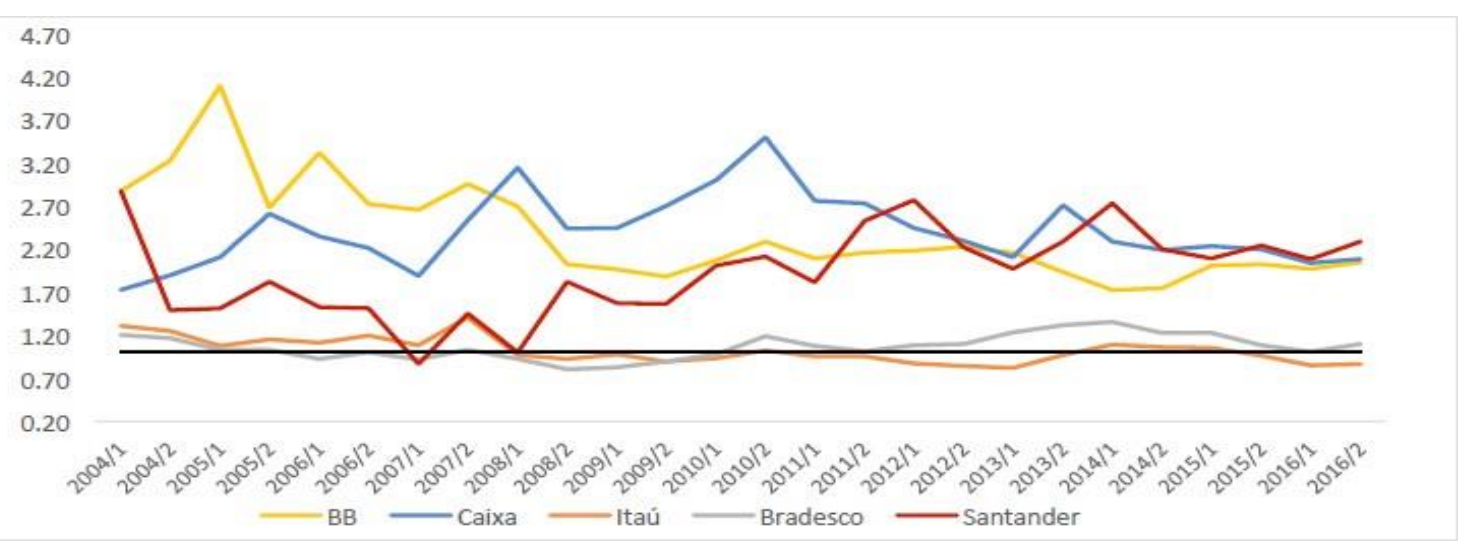

Fonte. Retirado de Mendonça e Cavalcante (2018)

Após demonstrar como se comportou a oferta de crédito e as posturas financeiras assumidas pelos grandes bancos, torna-se preponderante analisar como os cinco maiores conglomerados financeiros - a saber: Banco do Brasil, Itaú, Bradesco, Caixa Econômica Federal e Santander - geriram sua estrutura patrimonial nas diferentes fases do ciclo econômico. A análise será feita através da elaboração de dois indicadores, a saber: I) Ativo Total/ Patrimônio Líquido e II) Operações de Crédito/ Patrimônio Líquido. Os indicadores supracitados têm como objetivo avaliar o grau de alavancagem dos cinco maiores conglomerados no decorrer do ciclo econômico que caracterizou a economia brasileira entre os anos 2007 a 2016. Defende-se que entre os anos com expansão da atividade econômica os bancos ampliaram a proporção de ativos, principalmente as operações de crédito, com relação ao patrimônio líquido.

Com relação a análise dos ativos de cada instituição financeira, será analisado a proporção de operações como as de crédito e aplicações financeira em títulos, a fim de apontar quais estratégias na gestão patrimonial foram utilizadas no decorrer dos ciclos econômicos. Defende-se que em momentos de expansão da atividade econômica os bancos, em busca de maiores rendimentos, ampliam as operações de crédito e reduzem 
aplicações financeira em títulos. Já em momentos de retração da atividade econômica as operações supracitadas se invertem conforme demonstrado no Quadro 1. Utilizou-se no decorrer do presente trabalho informações contábeis das instituições financeiras que atuam no Brasil disponibilizadas na plataforma IF data pelo Banco Central do Brasil.

\subsection{ITAÚ}

O Gráfico 5 demonstra que o Itaú apresentou expansão dos ativos em relação ao patrimônio líquido no decorrer do ano de 2007, já no biênio 2008-2009 o banco apresentou quedas expressivas no seu grau de alavancagem, devido ao período de grave incerteza com relação ao futuro da economia brasileira graças a crise econômica que afetou os Estados Unidos e gerou efeitos negativos na economia brasileira. Entre os anos 2010 até o final de 2014, verifica-se que o Banco ampliou a proporção de ativos com relação ao seu capital próprio, se expondo a maiores riscos. Já no triênio 2015-2017 verifica-se que o banco reduziu seu processo de alavancagem. No que se refere a proporção de operações de crédito - ativos com maior rendimento e menor margem de segurança-com relação ao patrimônio líquido (Gráfico 6), verifica-se que o Itaú ampliou a participação deste ativo durante todo o período de crescimento da economia brasileira (2007 - 2013). Ampliando, portanto, seu grau de alavancagem e exposição ao risco. Este processo de expansão da alavancagem cessou entre os anos 2015 a 2017 em que a economia brasileira passou por um grave período de queda da atividade econômica e incerteza.

Gráfico 5 - Ativo Total (R \$ bilhões) sobre Patrimônio Líquido (R \$ bilhões) do Banco Itaú

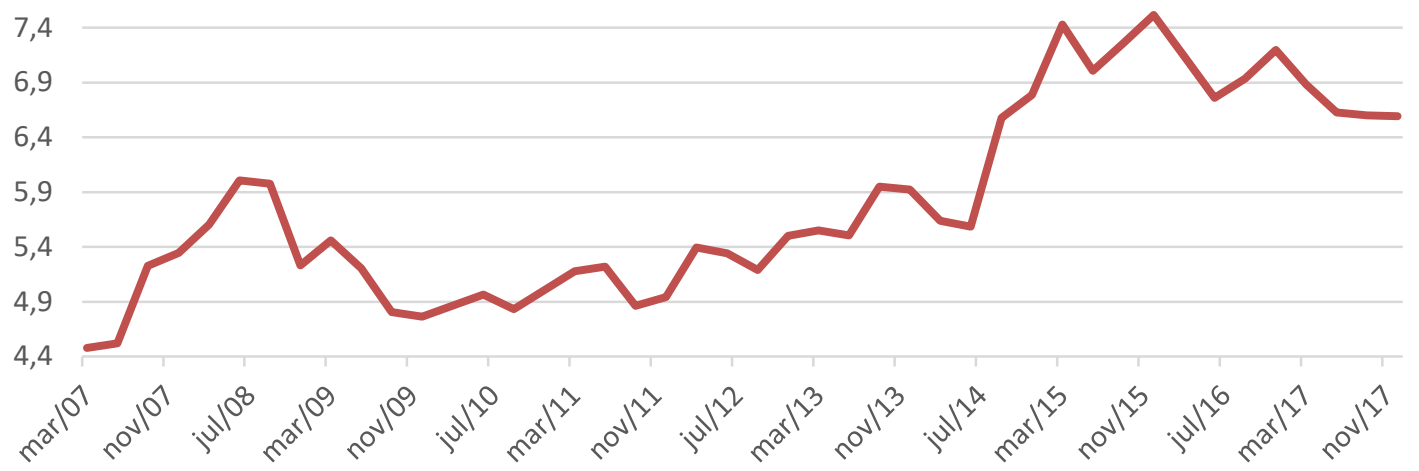

Fonte: Elaborado pelos autores a partir dos dados do IF data Banco Central do Brasil (2017) Gráfico 6 - Operações de Crédito (R \$ bilhões) sobre Patrimônio Líquido (R \$ bilhões) do Banco Itaú

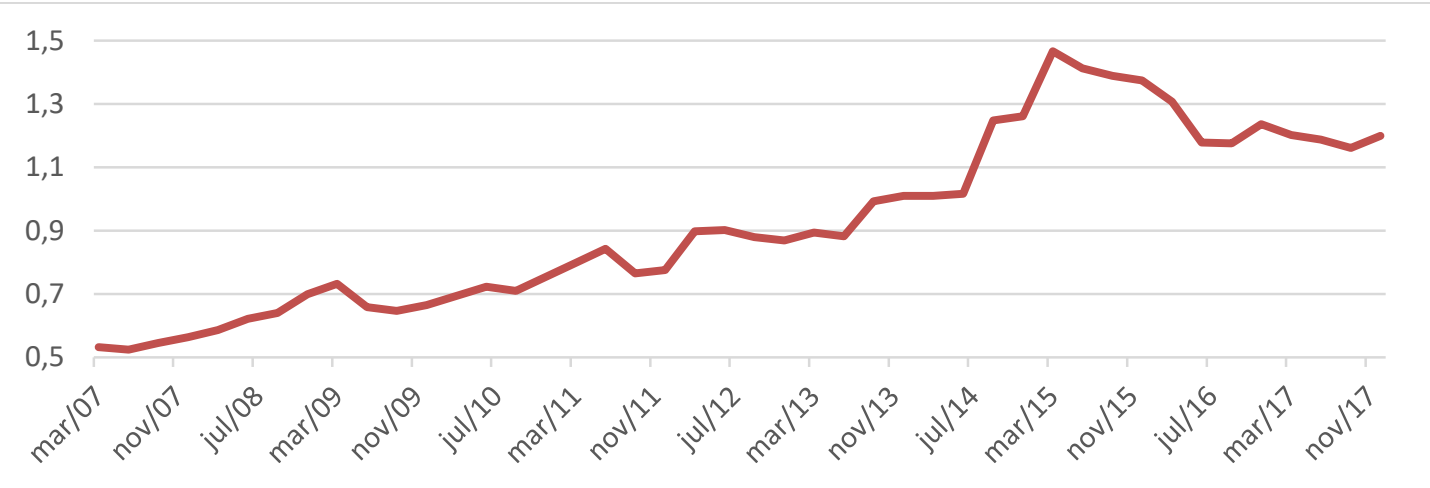

Fonte: Elaborado pelos autores a partir dos dados do IF data Banco Central do Brasil (2017) 
No que se refere à composição dos ativos do Banco Itaú, verifica-se que no período de crescimento da economia brasileira, o banco ampliou constantemente a proporção de operações de crédito em sua estrutura patrimonial até setembro de $2015 \mathrm{em}$ que o ativo alcançou cerca de $20 \%$ na composição do ativo total do banco. Já no que tange aplicações financeiras em títulos se verifica um comportamento instável - oscilando em torno de $13 \%$ a $19 \%$ - em sua participação na composição do ativo total, no período de crescimento econômico. Portanto, na gestão de sua estrutura patrimonial observa-se expansão de ativos com maior rendimento e menor margem de segurança nos anos de expansão da atividade econômica descritos pelas operações de crédito (Gráfico 7) e um comportamento instável, apesar da tendência de crescimento nos anos analisados, no que se refere a ativos com maior margem de segurança caracterizado pelos títulos (Gráfico 8).

Com relação ao período de retração da atividade econômica, nota-se retração das operações de crédito entre 2015 a 2017 com relação ao ano de 2014 (Gráfico 7) e expansão das aplicações financeiras em títulos a partir do final de 2014 se perpetuando até o início de 2016 (Gráfico 8). Pode-se então apontar que no período descendente da atividade econômica brasileira o banco Itaú ampliou em seu portfólio ativos com menor rendimentos, porém com maior liquidez e segurança.

Gráfico 7 - Operações de Crédito (R \$ bilhões) sobre Ativo Total (R \$ bilhões) do Banco Itaú

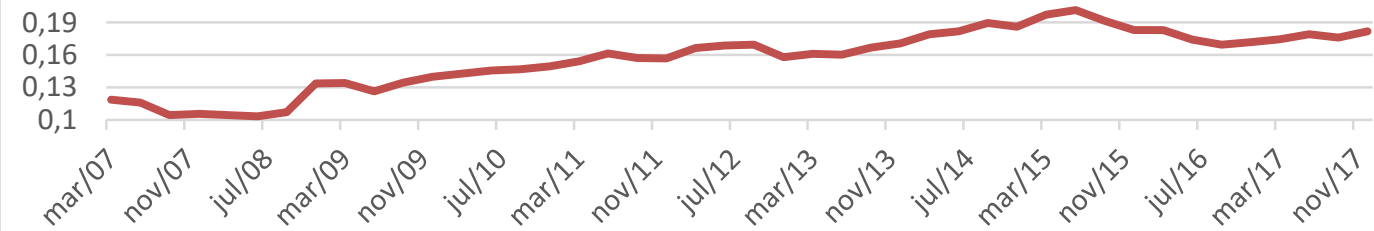

Fonte: Elaborado pelos autores a partir dos dados do IF data Banco Central do Brasil (2017)

Gráfico 8 - Aplicações em Títulos (R \$ bilhões) Ativo Total (R \$ bilhões) do Banco Itaú

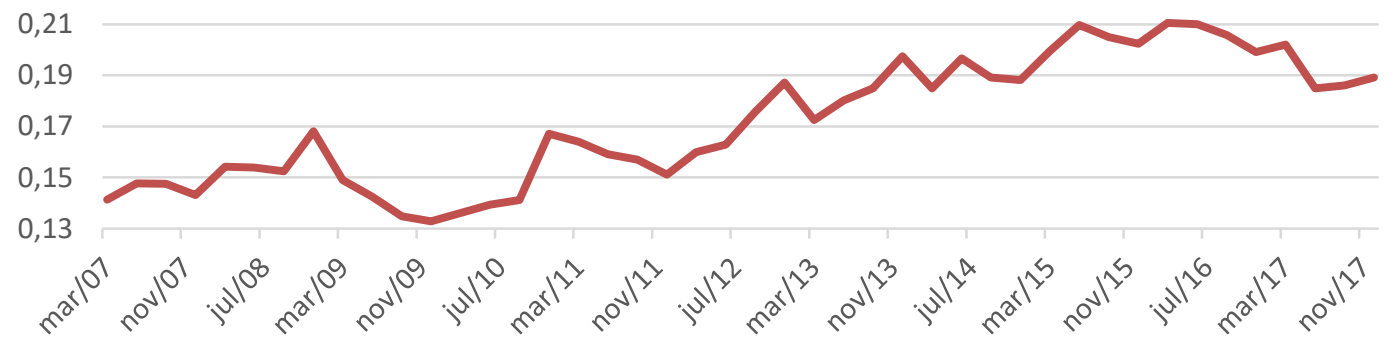

Fonte: Elaborado pelos autores a partir dos dados do IF data Banco Central do Brasil (2017)

\subsection{BRADESCO}

O Gráfico 9 demonstra que o Bradesco, por sua vez, apresentou surpreendentemente queda no grau de alavancagem medidos pelo índice ativo total/ patrimônio líquido no período de expansão da atividade econômica brasileira (20072013). Ainda no que se refere ao período de crescimento econômico, pode-se verificar no gráfico 10 que o banco reduziu suas operações de crédito em proporção ao patrimônio líquido entre os anos 2007 e 2009 e as manteve praticamente constante entre os anos 2010 a 2013 - excetuando uma leve queda entre os anos 2012 e 2013. Os resultados supracitados são surpreendentes pois se espera uma crescente exposição ao risco das instituições financeiras no período de crescimento econômico. Já no período de retração 
da atividade econômica (2014-2016), verifica-se crescimento das operações de crédito em relação ao patrimônio líquido (Gráfico 10) e expansão do ativo total com relação também ao capital próprio da instituição (Gráfico 9).

Gráfico 9 - Ativo Total ( $\mathrm{R}$ bilhões) sobre Patrimônio Líquido ( $\mathrm{R}$ bilhões) do Banco Bradesco

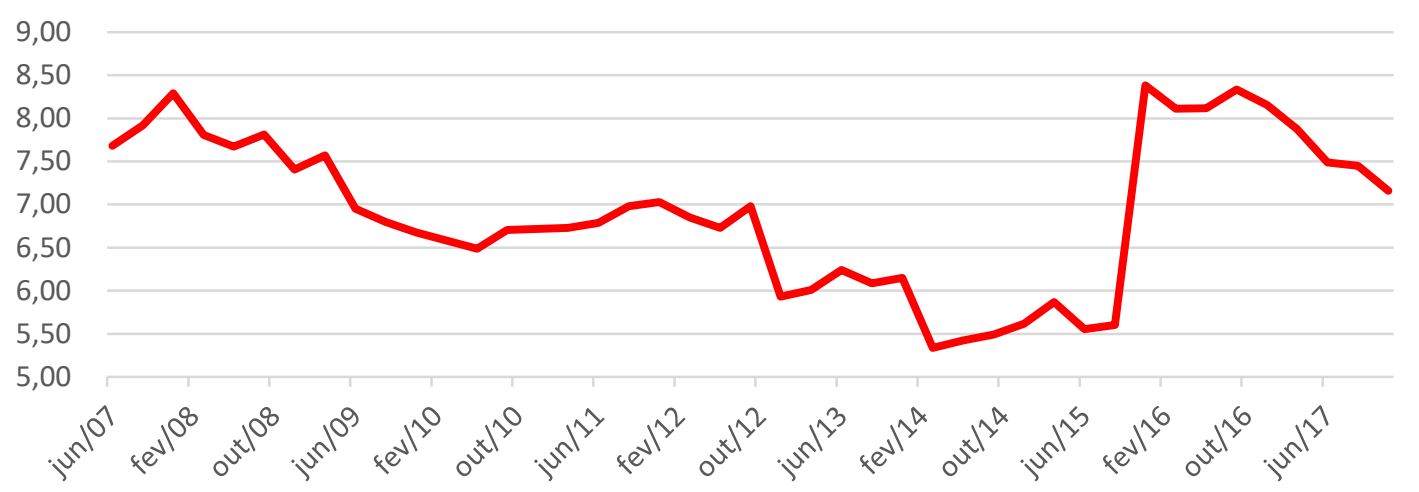

Fonte: Elaborado pelos autores a partir dos dados do IF data Banco Central do Brasil (2017)

Gráfico 10 - Operações de Crédito ( $\mathrm{R}$ \$ bilhões) sobre Patrimônio Líquido (R \$ bilhões) do Banco Bradesco

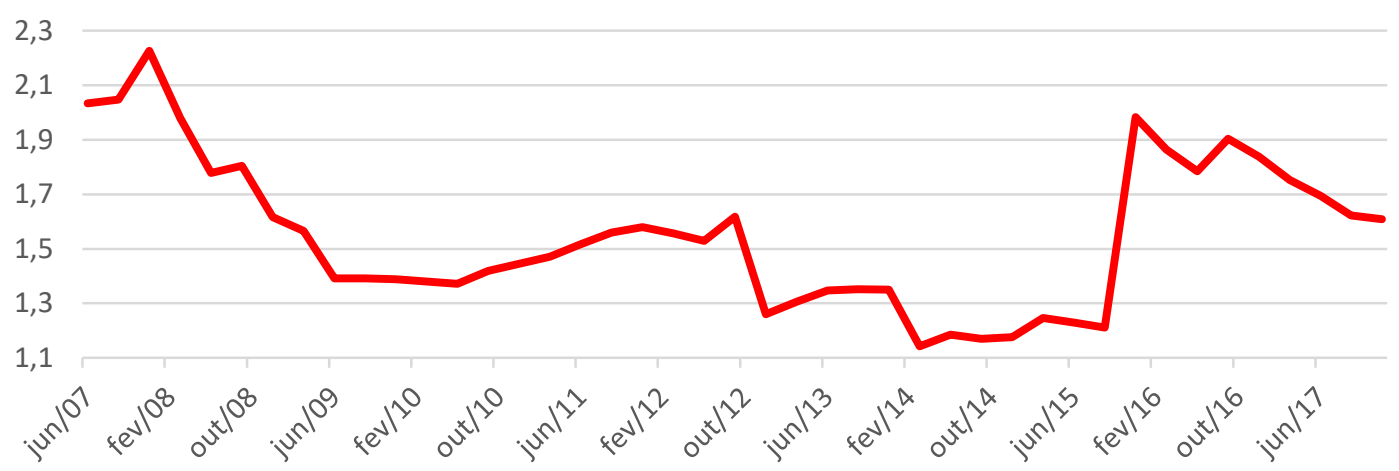

Fonte: Elaborado pelos autores a partir dos dados do IF data Banco Central do Brasil (2017)

A Tabela 2 demonstra que as operações de crédito oscilaram entre $21 \%$ a $26 \%$ na composição dos ativos totais do Bradesco, não apresentando grandes variações entre os anos que caracterizam os ciclos econômicos descritos no decorrer deste trabalho. Vale ressaltar, entretanto, que o Bradesco apresenta uma porcentagem maior de concessão de crédito na composição de seus ativos se comparado com o Banco Itaú analisado anteriormente.

Já a participação das aplicações financeira em títulos na estrutura de ativos do banco chama atenção. Nota-se crescimento expressivo destes ativos nos anos de crise econômica, no final de 2013 (último ano do ciclo econômico expansivo) os títulos compreendiam cerca 19\% dos ativos do banco, já em 2016 este percentual sobe para $26 \%$, demonstrando que a instituição financeira no momento de grande incerteza pelo qual a economia brasileira passou no biênio 2015-2016, ampliou a participação de ativos que trazem menores rendimentos porém maior liquidez e segurança.

No que se refere a participação das disponibilidades no ativo total verifica-se, na tabela 2, que no período de expansão da atividade econômica, este ativo oscila em torno de $0,8 \%$ a 1,7\%. Em 2015, primeiro ano de recessão na economia brasileira, o ativo compõe cerca de $2,9 \%$ do ativo total do banco Bradesco demonstrando uma crescente 
preocupação com relação a liquidez dos ativos do banco. Em 2016, por sua vez, o banco reduz as disponibilidades na composição de seus ativos para $1,5 \%$.

Tabela 2 - Composição do Ativo Total (Operações financeiras selecionadas) - Banco Bradesco

\begin{tabular}{cccc}
\hline Período & $\begin{array}{c}\text { Op. de } \\
\text { crédito }\end{array}$ & Títulos & Disponibilidade \\
\hline jun/07 & $26 \%$ & $17 \%$ & $1,40 \%$ \\
set/08 & $23 \%$ & $16 \%$ & $1,10 \%$ \\
mar/09 & $21 \%$ & $14 \%$ & $0,80 \%$ \\
jun/10 & $21 \%$ & $14 \%$ & $0,80 \%$ \\
dez/11 & $22 \%$ & $21 \%$ & $1,70 \%$ \\
set/12 & $23 \%$ & $23 \%$ & $0,90 \%$ \\
dez/13 & $21 \%$ & $19 \%$ & $1,20 \%$ \\
set/14 & $21 \%$ & $19 \%$ & $0,70 \%$ \\
dez/15 & $24 \%$ & $24 \%$ & $2,90 \%$ \\
set/16 & $23 \%$ & $26 \%$ & $1,50 \%$ \\
dez/17 & $22 \%$ & $27 \%$ & $1,05 \%$ \\
\hline
\end{tabular}

Fonte: Elaborado pelos autores a partir dos dados do IF data Banco Central do Brasil (2017)

\subsection{SANTANDER}

O banco Santander - único banco analisado sob controle estrangeiro - apresentou drástica queda nos índices de alavancagem no ano de 2008 devido a grave crise econômica que afetou a economia mundial e desencadeou queda brusca dos ativos do banco. Apesar disto, o comportamento do índice ativo total/ patrimônio líquido e operações de crédito/Patrimônio líquido (Gráficos 11 e 12) apontam para uma recuperação do grau de alavancagem no decorrer dos outros anos que caracterizaram o ciclo econômico expansivo da economia brasileira (2007-2013).

No decorrer dos anos de retração da atividade econômica há estagnação no que se refere ao grau de patrimônio líquido comprometido pelo ativo total, excetuando-se uma expressiva queda no início de 2017 (Gráfico 11). Já no que se refere as operações de crédito em relação ao capital próprio do banco Santander, o gráfico 12 aponta que a partir do final de 2013, o banco reduziu seu grau de exposição a riscos, estagnando o processo de alavancagem.

Gráfico 11 - Ativo Total (R\$ bilhões) sobre Patrimônio Líquido (R \$ bilhões) do Banco Santander

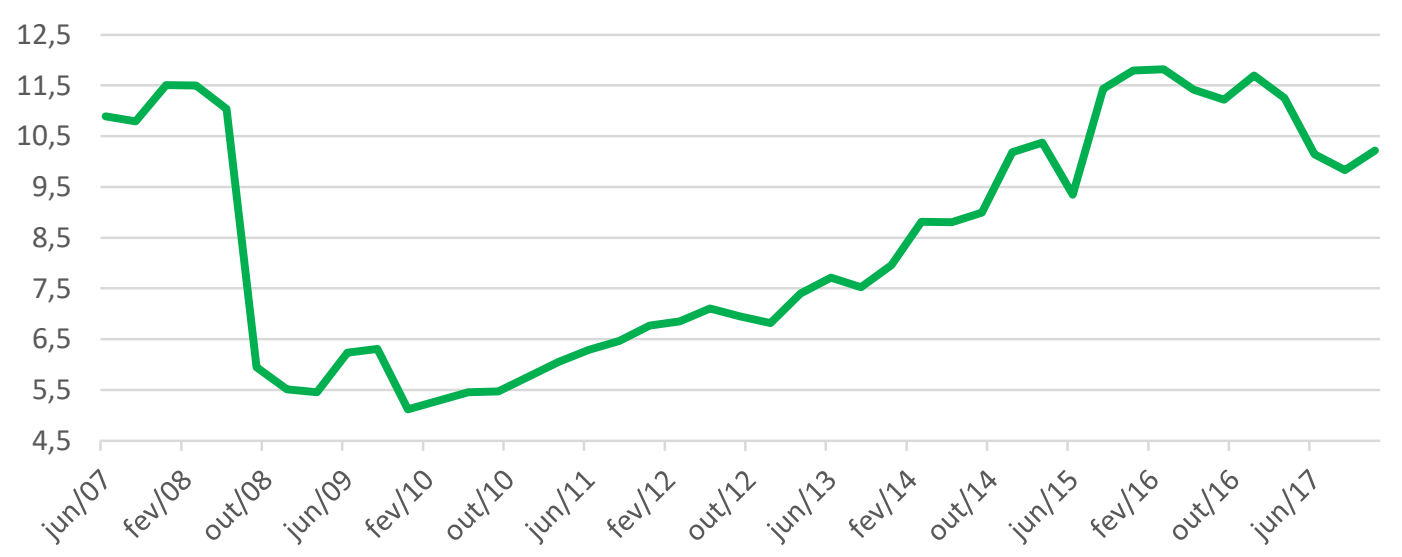

Fonte: Elaborado pelos autores a partir dos dados do IF data Banco Central do Brasil (2017) 
Gráfico 12 - Operações de Crédito (R \$ bilhões) sobre Patrimônio Líquido (R \$ bilhões) do Banco Santander

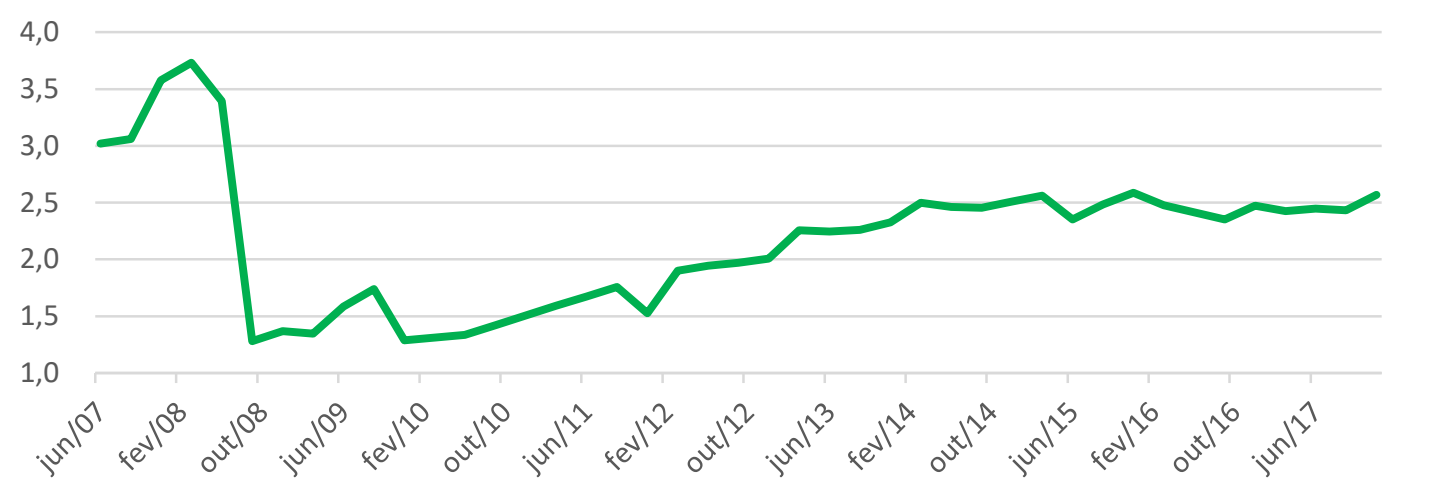

Fonte: Elaborado pelos autores a partir dos dados do IF data Banco Central do Brasil (2017)

No que se refere a composição dos ativos do banco Santander, se verifica um comportamento instável entre os anos de expansão da atividade econômica brasileira caracterizada por expressivas quedas nas operações de crédito nos anos 2008,2009 e 2012 (anos de graves crises na economia mundial) e ampliações nas concessão de créditos a partir do final de 2009 até 2014, anos marcado por melhorias nas expectativas internacionais e da economia brasileira. Nota-se, entretanto, queda expressiva das operações de crédito em proporção aos ativos nos anos de retração da atividade econômica. A partir de 2014 o banco Santander reduz as operações que apresentam menor margem de segurança e liquidez (Gráfico 13) e ampliam a participação de títulos ativos com menor rendimento e maior margem de segurança - vertiginosamente em seu portfólio (Gráfico 14).

Gráfico 13 - Operações de Crédito (R \$ bilhões) sobre Ativo total (R \$ bilhões) do Banco Santander

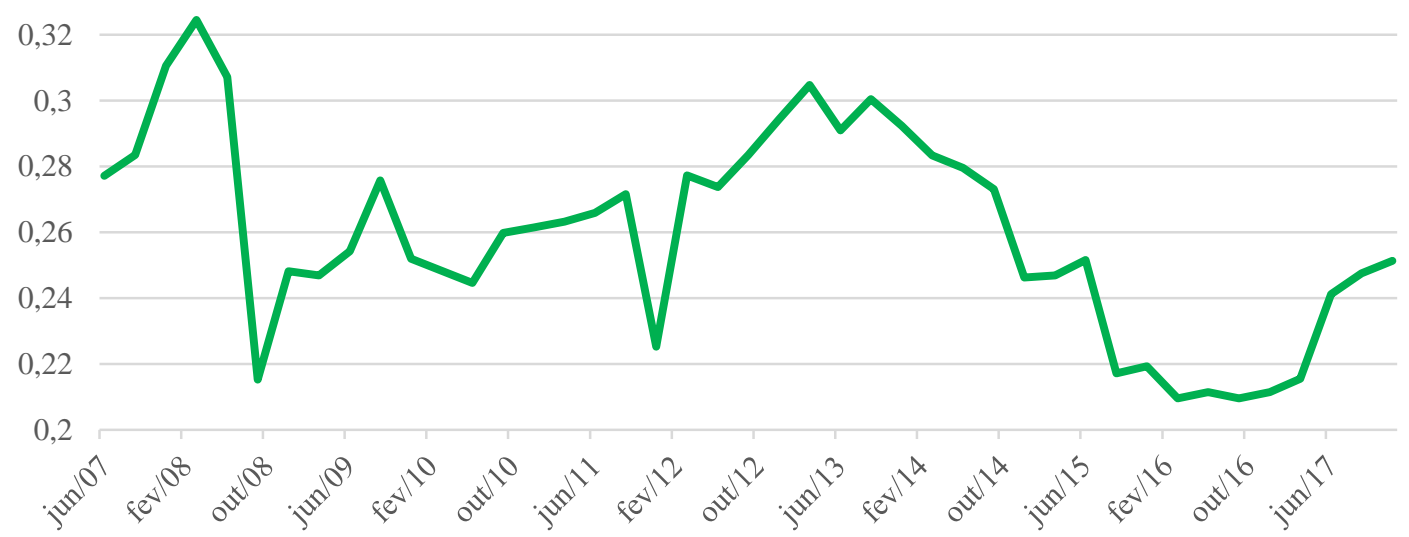

Fonte: Elaborado pelos autores a partir dos dados do IF data Banco Central do Brasil (2017) 
Gráfico 14 - Aplicações de Títulos (R $\$$ bilhões) sobre Ativo Total (R \$ bilhões) do Banco Santander

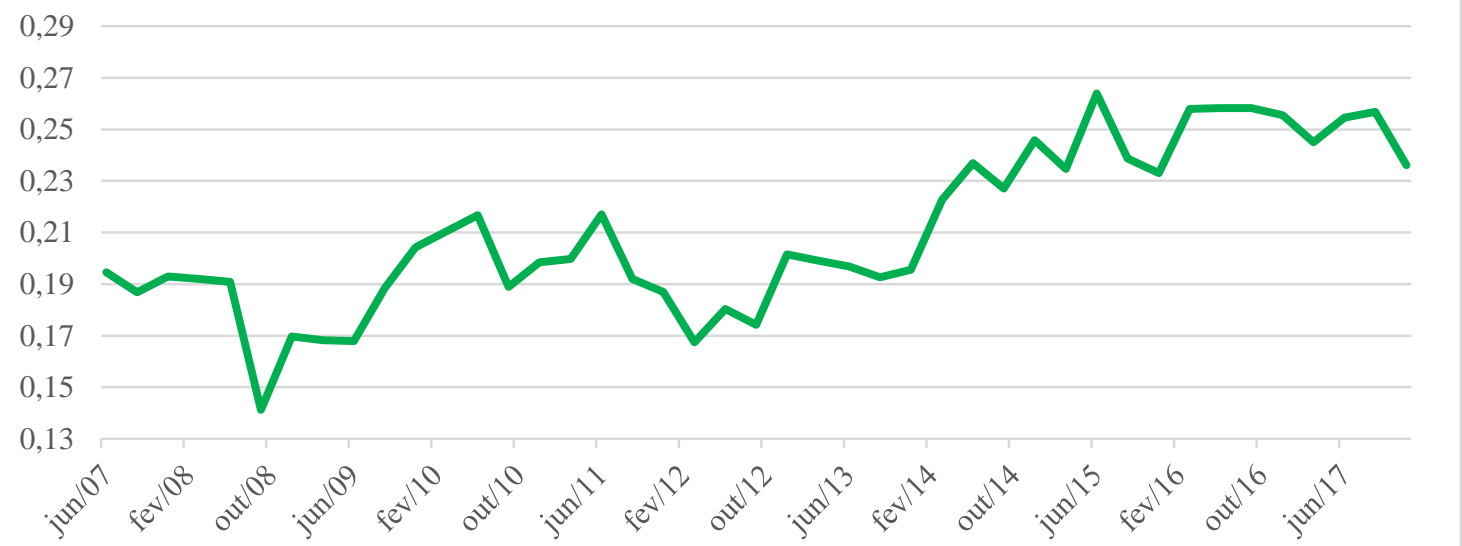

Fonte: Elaborado pelos autores a partir dos dados do IF data Banco Central do Brasil (2017)

\subsection{CAIXA ECONÔMICA FEDERAL E BANCO DO BRASIL}

A Caixa Econômica Federal (CEF) apresentou dinâmica diferente com relação ao comportamento dos bancos privados analisados neste trabalho até o momento. Os bancos públicos foram inseridos de forma intensiva no ciclo de expansão de crédito da economia brasileira, principalmente após a inflexão nas políticas macroeconômicas no segundo mandato do governo Luiz Inácio Lula da Silva. Os gráficos 15 e 16, demonstram um crescimento expressivo da alavancagem da Caixa Econômica Federal que ampliou em todos os anos a proporção de ativos em relação ao seu patrimônio líquido - chegando a 45\% em 2015 - e ampliou também operações de crédito que detém maior rendimento e menor margem de segurança em praticamente todos os anos.

Gráfico 15 - Ativo Total (R \$ bilhões) sobre Patrimônio Líquido (R \$ bilhões) da Caixa Econômica Federal

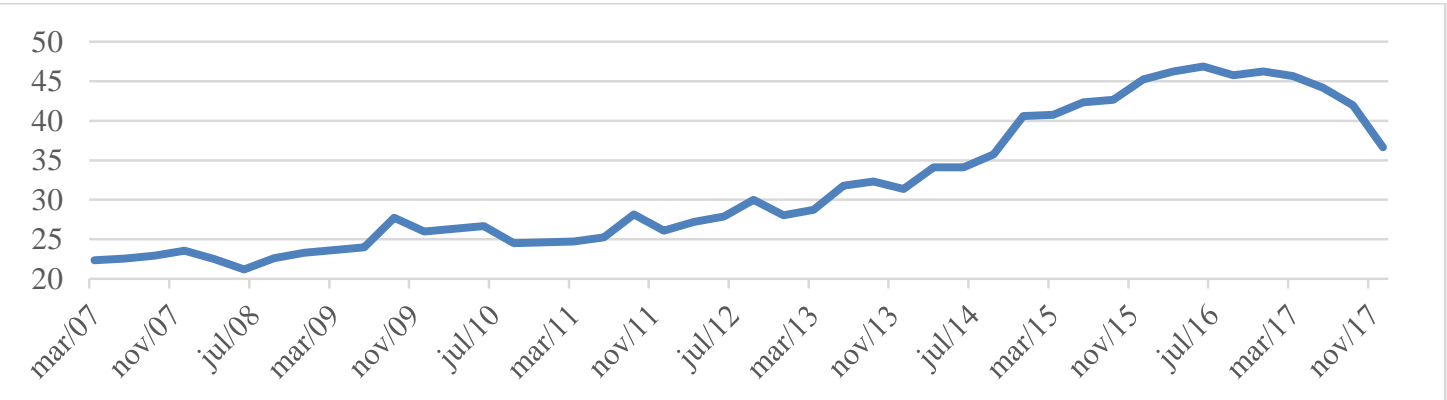

Fonte: Elaborado pelos autores a partir dos dados do IF data Banco Central do Brasil (2017) 
Gráfico 16 - Operações de Crédito (R \$ bilhões) sobre Patrimônio Líquido (R \$ bilhões) da Caixa Econômica Federal

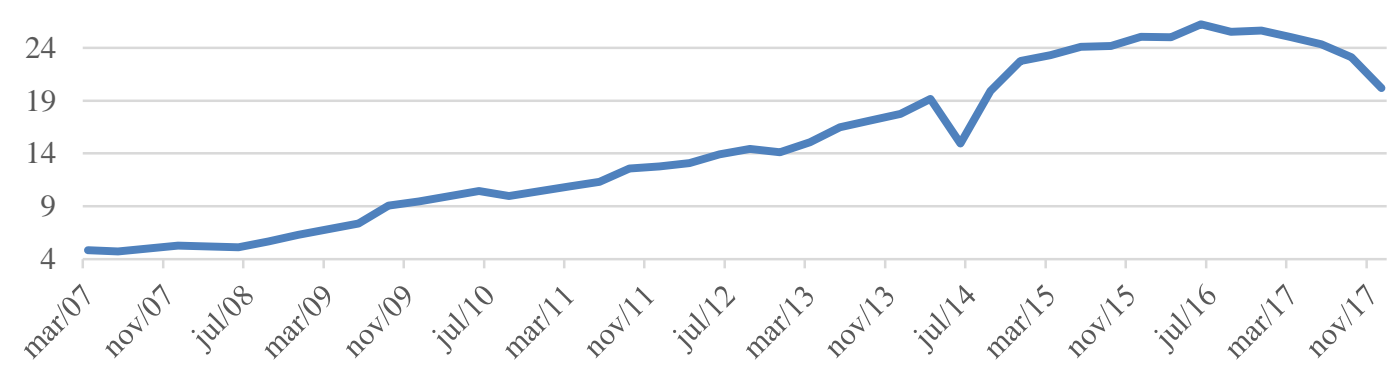

Fonte: Elaborado pelos autores a partir dos dados do IF data Banco Central do Brasil (2017)

Os bancos públicos, portanto, agiram de maneira anticíclica, ampliando as operações de crédito em momentos de retração da atividade econômica, como se pode notar nos anos de 2008 e 2009 marcados por quedas nos indicadores macroeconômicos. Se torna preponderante considerar que no decorrer do biênio 2016-2017 em que há uma política deliberada de ajuste neoliberal em que se prega a redução de políticas econômicas capitaneadas pelo Estado a fim de restaurar o processo de crescimento econômico, a Caixa Econômica Federal reduz sua participação na concessão de crédito no mercado. No que se refere a composição dos ativos da CEF, as operações de crédito correspondem a mais que a metade dos ativos do banco no auge do ciclo econômico, chegando a 56\% deste em 2013 (Gráfico 17). O processo supracitado apresenta estagnação nos anos de retração da atividade econômica.

No que se refere as aplicações financeiras em títulos na composição dos ativos da CEF, o Gráfico 18 demonstra que há queda sistemática e constante até 2015. A partir deste momento há uma estagnação dessas operações. Já com relação a composição dos ativos do Banco do Brasil se verifica uma grande proporção do balancete comprometida em operações de crédito oscilando em torno de $37 \%$ em junho de 2007 a $44 \%$ em dezembro de 2013. Já com relação a participação dos títulos financeiros no ativo total, há retração dessas aplicações nos anos de expansão da atividade econômica (2007 a 2013) e relativa ampliação da participação desses ativos entre 2014 e 2016 conforme demonstrado na Tabela 3.

Gráfico 17 - Operações de Crédito (R \$ bilhões) sobre Ativo Total (R \$ bilhões) da Caixa Econômica Federal

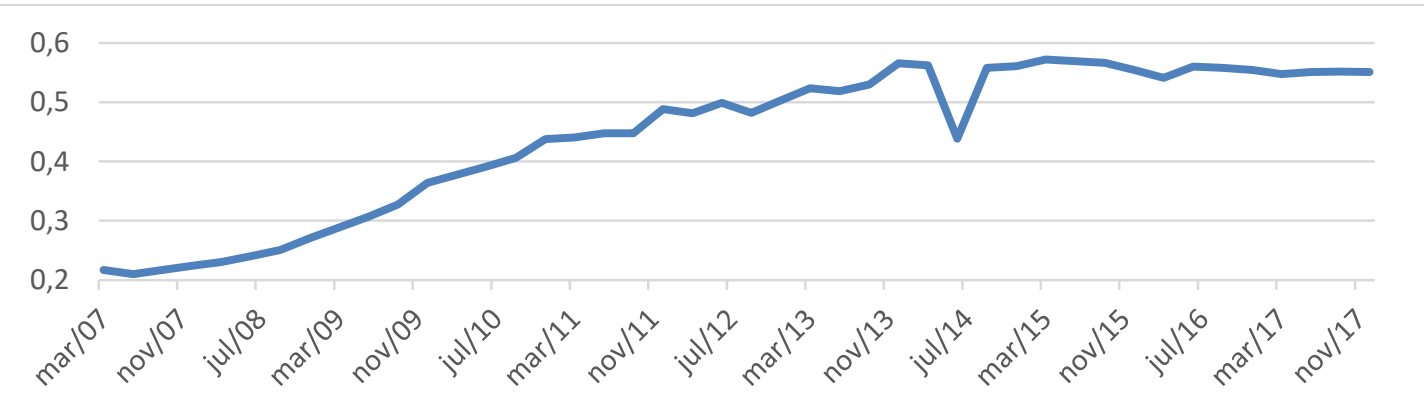

Fonte: Elaborado pelos autores a partir dos dados do IF data Banco Central do Brasil (2017) 
Gráfico 18 - Aplicações em Títulos (R \$ bilhões) sobre Ativo Total (R \$ bilhões) da Caixa Econômica Federal

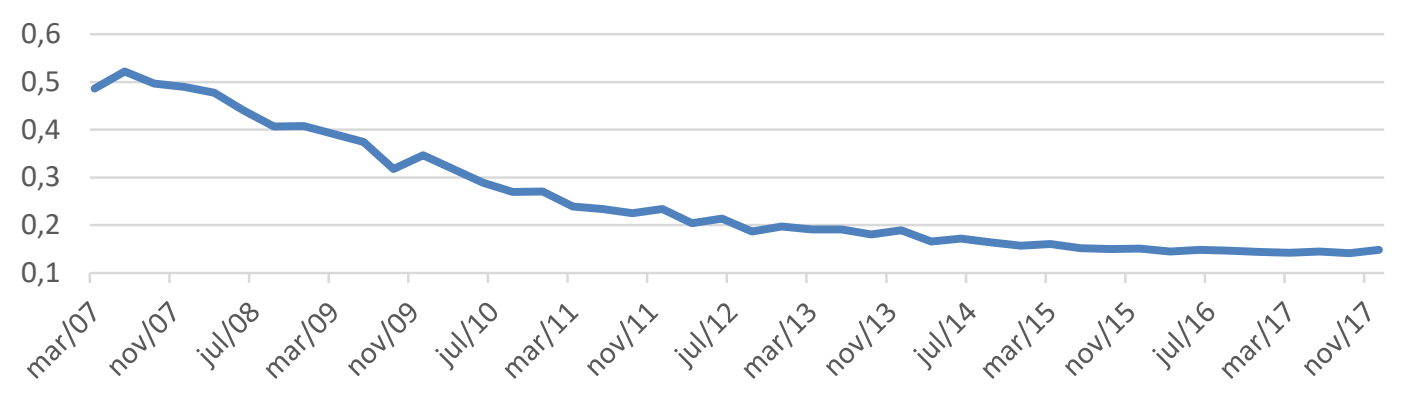

Fonte: Elaborado pelos autores a partir dos dados do IF data Banco Central do Brasil (2017)

Tabela 3 - Composição do Ativo Total (Variáveis selecionadas) - Banco do Brasil

\begin{tabular}{rrr}
\hline Período & $\begin{array}{c}\text { Op. de } \\
\text { crédito }\end{array}$ & Títulos \\
\hline jun/07 & $37 \%$ & $21 \%$ \\
set/08 & $40 \%$ & $16 \%$ \\
$\mathrm{mar} / 09$ & $37 \%$ & $17 \%$ \\
$\mathrm{jun} / 10$ & $40 \%$ & $13 \%$ \\
$\mathrm{dez} / 11$ & $40 \%$ & $12 \%$ \\
$\mathrm{set} / 12$ & $40 \%$ & $10 \%$ \\
$\mathrm{dez} / 13$ & $44 \%$ & $12 \%$ \\
$\mathrm{set} / 14$ & $42 \%$ & $14 \%$ \\
$\mathrm{mar} / 15$ & $41 \%$ & $14 \%$ \\
$\mathrm{set} / 16$ & $38 \%$ & $15 \%$ \\
$\mathrm{dez} / 17$ & $40 \%$ & $11 \%$ \\
\hline
\end{tabular}

Fonte: IF data Banco Central do Brasil - Elaboração Própria (2017)

Importante salientar que o Banco do Brasil, apresentou tanto na proporção de seus ativos com relação ao capital próprio, quanto nas operações de crédito em relação ao patrimônio líquido, ampliações de seus processos de alavancagem nos momentos de crise econômica com o objetivo de sustentar a oferta de crédito na economia brasileira. Os Gráficos 19 e 20 apontam para expansão das operações do Banco do Brasil tanto no biênio 2008-2009, quanto no biênio 2014-2015. No ano de 2016, entretanto, se observa queda nos indicadores de alavancagem da instituição financeira. Se tornar importante salientar, entretanto, que o Banco do Brasil apresenta menor grau de alavancagem com relação ao seu patrimônio líquido quando comparado com os resultados da Caixa Econômica Federal demonstrados anteriormente. 
Gráfico 19 - Ativo Total (R \$ bilhões) sobre Patrimônio Líquido (R \$ bilhões) do Banco do Brasil

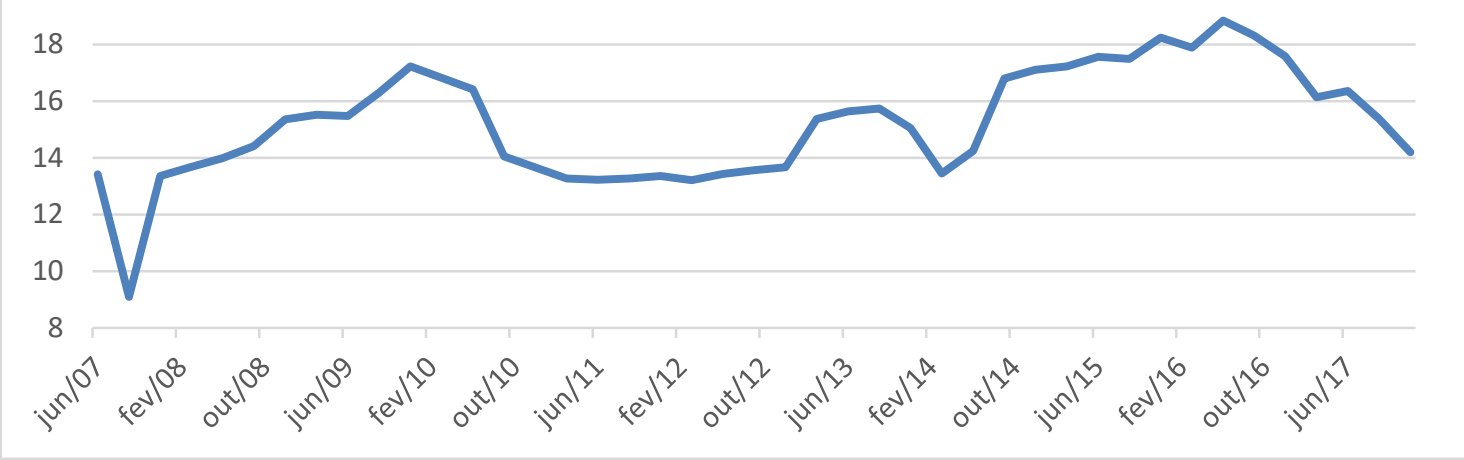

Fonte: Elaborado pelos autores a partir dos dados do IF data Banco Central do Brasil (2017)

Gráfico 20 - Operações de Crédito (R \$ bilhões) sobre Patrimônio Líquido (R \$ bilhões) do Banco do Brasil

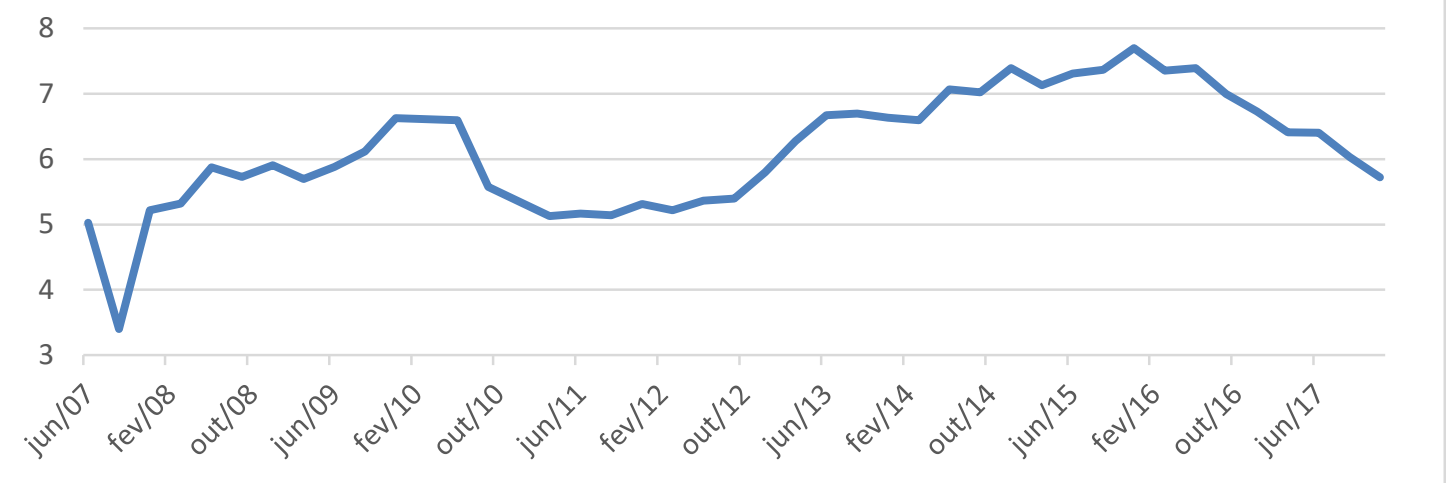

Fonte: Elaborado pelos autores a partir dos dados do IF data Banco Central do Brasil (2017)

\section{CONCLUSÃO}

O trabalho objetivou analisar, sob a perspectiva teórica da Hipótese da Fragilidade Financeira elaborada por Minsky (1986, 1992), como os cinco maiores conglomerados financeiros que atuam na economia brasileira se comportaram na gestão de sua estrutura patrimonial no período que compreende aos anos 2007 a 2016. Como descrito anteriormente, o período supracitado apresenta importantes inflexões na evolução do cenário macroeconômico, caracterizado por períodos de considerável crescimento econômico (2007 a 2013) e de grave retração nos indicadores da atividade macroeconômica (2014 a 2016). Consequentemente aponta-se para alterações nas estratégias das instituições financeira no que se refere à composição de seus portfólios e em seus respectivos graus de alavancagem.

Defende-se que no período de expansão de atividade econômica os grandes conglomerados financeiros, graças ao otimismo que vigorou na economia brasileira, tenham expandindo o grau de alavancagem de suas operações ampliando consequentemente a proporção de ativos que possuam maior rentabilidade e menor grau de liquidez. Já no período de retração dos indicadores macroeconômicos parte-se da hipótese que houve alterações significativas na gestão da estrutura patrimonial das instituições financeiras. Nestes momentos os bancos tendem a reduzir o grau de alavancagem de suas operações e alteram a estrutura da composição de seus balancetes, 
ampliando, por sua vez, a participação de ativos que possuam maior liquidez e menor rentabilidade. Após a elaboração de indicadores que auferem o grau de alavancagem e a análise da evolução das estruturas patrimoniais dos grandes conglomerados financeiros observou-se que todas as instituições financeiras privadas analisadas no decorrer do presente trabalho, com exceção do Bradesco, apresentaram expansões nos indicadores de alavancagem e na participação das operações de crédito no ativo total no período de crescimento econômico. Importante destacar ainda que no biênio 2008-2009 marcado por grave crise na economia mundial e deterioração das expectativas dos agentes econômicos há queda nos indicadores que auferem a alavancagem do banco Santander, porém esses indicadores voltam a se expandir após a implementação de políticas anticíclicas que geraram crescimento econômico.

O resultado supracitado aponta que os bancos analisados se comportaram na gestão de suas respectivas estruturas patrimoniais de acordo com a HFF (Quadro 1). Já no período de crise econômica, houve retração ou estagnação dos indicadores de alavancagem e contração da concessão de crédito em detrimento da expansão na proporção de aplicações de títulos nos ativos totais tanto no Itaú quanto no Santander. Os resultados apresentados vão ao encontro da HFF e consequentemente das hipóteses que nortearam o presente trabalho pois no período de crescimento econômico, os bancos privados (Itaú e Santander) optaram por operações com maior grau de rentabilidade e menor grau de liquidez (operações de crédito). Já nos períodos de incerteza e de retração dos indicadores macroeconômicos, as instituições financeiras optaram por ativos com maior grau de liquidez e menor rentabilidade (aplicações em títulos financeiros). Com relação a CEF, os dados demonstram que o banco apresentou expansão constante em seu grau de alavancagem nos períodos de crescimento econômico (2007 a 2013). Por sua vez, no período de retração da atividade econômica (2014 a 2016) há uma inflexão na trajetória dos indicadores de alavancagem que começam a apresentar queda a partir de 2016. Já com relação à gestão de sua estrutura patrimonial, a CEF apresentou crescimento constante da proporção de operações de crédito em relação aos ativos no período de crescimento econômico.

Já no decorrer dos anos de retração econômica há uma inflexão na proporção de operações de crédito em relação ao ativo total da CEF, fato que alterou a trajetória de expansão do indicador supracitado com relação aos anos anteriores. Cabe destacar a queda contínua da proporção de títulos em relação ao ativo total no período de crescimento econômico. Por sua vez, no decorrer dos anos de crise econômica o processo supracitado se reverte e o indicador permanece constante.

No que se refere ao comportamento do Banco do Brasil constata-se através dos dados analisados que a instituição financeira alavancou suas operações significativamente nos anos em que a economia brasileira sofreu impactos negativos em seus indicadores macroeconômicos (2008 e 2009) devido a grave crise econômica que afetou a economia mundial em 2008. A tendência de expansão também é notada no decorrer do primeiro mandato do governo Dilma Rousseff (2011 a 2014). Cabe ainda destacar a expansão contínua na participação das operações de crédito em relação ao ativo total entre os anos 2007 a 2013. Já nos anos de retração da atividade econômica há relativa queda na participação das operações de crédito na composição dos ativos do BB e relativo crescimento da participação de aplicações financeiras no ativo total do BB nos anos de crise econômica.

Chama atenção ainda o elevado grau de alavancagem dos bancos públicos quando comparados com o mesmo indicador dos bancos privados. Estes resultados demonstram 
que os bancos públicos foram utilizados como instrumentos de política econômica, no decorrer do período de crescimento econômica da economia brasileira (2007 a 2013) com o objetivo de ampliar o acesso ao crédito tanto a pessoas físicas quanto jurídicas e expandir a demanda agregada consequentemente.

Conclui-se, portanto, que os bancos públicos ampliaram o grau de exposição ao risco no decorrer do período de expansão da atividade econômica brasileira e em alguma medida reduziram a participação de operações financeiras com menor grau de liquidez no decorrer dos anos de retração do crescimento econômico corroborando com a HFF desenvolvida por Hyman Minsky. Como os bancos públicos são meios de política econômica anticíclica por parte do governo federal, os índices não apresentaram tanta volatilidade entre os anos 2014 a 2016 no que se refere as alterações na gestão patrimonial quando comparados aos indicadores dos bancos privados.

Cabe destacar que de acordo com os resultados encontrados, o Banco Bradesco não apresentou expansão nos graus de exposição ao risco no período de crescimento econômico, consequentemente foi o único banco analisado que não apresentou resultados condizentes com a HFF. Portanto, para trabalhos futuros, sugere-se a análise individual do banco supracitado a fim de explorar as especificidades de sua estrutura patrimonial no período analisado e a utilização de métodos estatísticos e econométricos para analisar o impacto do cenário macroeconômico e consequentemente das expectativas dos agentes econômicos na gestão da estrutura patrimonial das instituições financeiras que atuam no Brasil.

\section{REFERÊNCIAS}

BARBOSA, N.; SOUZA, J. A. P. DE. A Inflexão Do Governo Lula: Política Econômica, Crescimento E Distribuição De Renda. Brasil, entre o Passado e o Futuro, p. 1-42, 2010.

BIELSCHOWSKY, R.; SQUEFF, G. C.; VASCONCELOS, L. F. Evolução dos investimentos nas três fontes de expansão da economia brasileira na década de 2000. Brasília: IPEA, 2015. (Textos para Discussão, n. 2063)

CARDOSO JÚNIOR, J.; NAVARRO, C. O planejamento governamental no Brasil e a experiência recente (2007 a 2014) do Programa de Aceleração do Crescimento (PAC) Brasília: IPEA, 2016 (Textos para Discussão, n. 2174).

CORRÊA, M. F.; LEMOS, P. DE M.; FEIJO, C. Financeirização, empresas não financeiras e o ciclo econômico recente da economia brasileira. Economia e Sociedade, v. 26, n. Número Especial, p. 1127-1148, 2017.

FONSECA, A. DE O. A Hipótese de Fragilidade Financeira e a Recessão Brasileira de 2014-2017. Anais do XI Encontro da AKB. "Desafios para a Economia Brasileira: uma perspectiva keynesiana". Anais...Porto Alegre: Faculdade de Ciências Econômicas da UFRGS, 2018

KEYNES, J. M. A Teoria Geral do Emprego, Juro e da Moeda. São Paulo: Nova Cultura, 1996.

KLEIN, M. A. A theory of the banking firm. Journal of Monetary Economics, v. 1, n. 1, p. 123-128, jan. 1975.

LACERDA, A. C. DE. Dinâmica e evolução da crise: discutindo alternativas. Estudos 
Avançados, v. 31, n. 89, p. 37-49, abr. 2017.

MELLO, G.; ROSSI, P. Do industrialismo à austeridade : a política macro dos governos Dilma. Campinas: IE Unicamp, 2017. (Textos para Discussão, n. 309).

MENDONÇA, M. P.; CAVALCANTE, A. Fragilidade Financeira do setor bancário brasileiro. Anais do XI Encontro da AKB. "Desafios para a Economia Brasileira: uma perspectiva keynesiana". Anais...Porto Alegre: Faculdade de Ciências Econômicas da UFRGS, 2018

MINSKY, H. Stabilizing an Unstable Economy. Nova Haven: Yale University Press, 1986.

MINSKY, H. P. The Financial Instabiity Hypothesis. New York: Jerome Levy Economics Institute of Bard College, 1992 (Working Paper, No. 74).

PAULA, L. F. DE. Sistema Financeiro, bancos e financiamento da economia: uma abordagem keynesiana. 1. ed. Rio de Janeiro: Elsevier Brasil, 2015.

PAULA, L. F. DE; ALVES JÚNIOR, A. J. Comportamento dos bancos, percepçãao de risco e margem de segurança no ciclo minskiano. Análise Econômica, v. 21, n. 39, 2003.

SERRANO, F.; SUMMA, R. Demanda agregada e a desaceleração do crescimento econômico brasileiro de 2011 a 2014. Center for economic and policy research, p. 142, 2015.

SINGER, A. O Ensaio desenvolvimentista no primeiro mandato de Dilma Rousseff (2011-2014). Novos Estudos, v. 102, p. 43-71, 2015. 